Jurnal Kesehatan Hesti Wira Sakti vol 9 No 12021

ISSN 2302-4283 (print)

ISSN 2580-9571 (online)

Online di https://jurnal.poltekkes-soepraoen.ac.id

DOI: $10.47794 /$

\title{
KINERJA PETUGAS DALAM PENYEDIAAN BERKAS REKAM MEDIS RAWAT JALAN DI RUMAH SAKIT TK.II dr. SOEPRAOEN MALANG
}

\author{
Retno Dewi Prisusanti, Fita Rusdian Ikawati , Anis Ansyori ' Rengganis Ularan \\ ${ }^{1}$ ITSK RS dr. Soepraoen Kesdam V/ Brawijaya Malang
}

(Korespondensi : retnodewi2503@gmail.com, )

\begin{abstract}
Abstrak
Standar prosedur pelaksanaan penyediaan dokumen rekam medis pelayanan rawat jalan adalah 10 menit. Berdasarkan survey awal menggunakan sampel sebanyak 230 berkas rekam medis rawat jalan, menunjukkan bahwa dalam penyediaan berkas rekam medis rawat jalan rata-rata 20-30 menit, tidak sesuai dengan standar. Tujuan penelitian ini adalah mengetahui faktor yang berhubungan dengan kinerja petugas dalam penyediaan berkas rekam medis rawat jalan. Metode penelitian yang digunakan adalah kuantitatif analitik dengan design penelitian yang digunakan cross sectional study. Populasi dalam penelitian ini adalah petugas admission dan perekam medis yang berjumlah 61 orang. Menggunakan analisa bivariat tabel silang (contingency) antara variabel bebas dan variabel terikat dengan uji chi square. Hasil penelitian didapatkan bahwa faktor kompetensi (pengetahuan berhubungan dengan kinerja petugas $(P$ Value $=0,008$, POR $=5,800)$, dan komunikasi berhubungan dengan kinerja petugas $(P$ Value $=0,011, \mathrm{POR}=5,111)$. Kesimpulan: ada hubungan kompetensi (pengetahuan dan komunikasi) dengan kinerja petugas dalam penyediaan berkas rekam medis rawat jalan.
\end{abstract}

Kata Kunci: Kinerja Petugas, Penyediaan Berkas Rekam Medis Rawat Jalan.

\section{PERFORMANCE OF OFFICERS IN PROVISION OF MEDICAL RECORD FILES OUTCOMING IN RUMAH SAKIT TK.II dr. SOEPRAOEN MALANG Abstract}

Standard Implementation Procedure for providing medical record documents of outpatient services is 10 minutes. Based on the initial survey using a sample of 230 files of outpatient medical records, showed that in the provision of outpatient medical records on average 20 - 30 minutes, not in accordance with the standard. The purpose of this study is to determine the factors related to the performance of officers in the provision of outpatient medical records. The research method used is quantitative analytical research design used cross sectional study. The population in this study was admission officers and medical recorders numbering 61 people. Using contingency bivariate analysis between free variables and variables bound to chi square test. The results of the study can be known that from 61 respondents competency factors (knowledge related to officer performance $(P$ Value $=$ $0.008, P O R=5,800)$, and communication related to officer performance $(P$ Value $=0.011, P O R=$ 5.111). The conclusion of this study is that there are factors related to competence (knowledge and communication) with the performance of officers in the provision of outpatient medical records.

Key word: officer performance, paper, medical record 


\section{PENDAHULUAN}

Rumah sakit merupakan tempat pelayanan kesehatan. Di mana rumah sakit memberikan dua jenis pelayanan kepada

Salah satu bentuk pelayanan administrasi yang diberikan di rumah sakit berupa penyelenggaran rekam medis. Penyelenggaraan rekam medis adalah merupakan proses kegiatan yang dimulai pada saat diterimanya pasien di rumah sakit,

diteruskan kegiatan pencatatan data medis pasien selama pasien itu mendapatkan pelayanan medis di rumah sakit, dan dilanjutkan dengan penanganan berkas rekam medis yang meliputi penyelenggaraan penyimpanan untuk melayani permintaan dari pasien atau untuk keperluan lainnya (Depkes RI, 1997). Untuk itu pelayanan rekam medis yang diberikan harus berkualitas dan sesuai dengan standar pelayanan yang ada.

Waktu tunggu merupakan salah satu indikator kinerja sumber daya manusia dalam memberikan pelayanan kepada pelanggan. Dalam pelayanan di rumah sakit, waktu tunggu adalah waktu yang dipergunakan oleh pasien untuk mendapatkan pelayanan rawat jalan dan rawat inap dari tempat pandaftaran sampai masuk ke ruang pemeriksaan dokter (Depkes RI, 2007).

Pelayanan rekam medis yang baik dan bermutu tercermin dari minimnya waktu tunggu pasien untuk memperoleh kartu registrasi sampai memperoleh pelayanan kesehatan yang dibutuhkannya, dan penataan dokumen rekam medik. Berdasarkan standar penyediaan dokumen rekam medis pelayanan rawat jalan adalah 10 menit (Depkes RI, 2007).
Berdasarkan hasil survei awal di Rumah Sakit TK.II dr.Soepraoen dengan menghitung waktu tunggu penyediaan berkas rekam medis pasien rawat jalan dengan menggunakan sampel sebanyak 230 berkas rekam medis rawat jalan, menunjukkan bahwa penyediaan berkas rekam medis rawat jalan dibutuhkan waktu rata-rata 20-30 menit. Jumlah pengunjung pasien Rawat jalan di Rumah Sakit TK.II dr. Soepraoen rata-rata 400 pasien per hari.

\section{METODE}

Jenis penelitian yang digunakan yaitu kuantitatif analitik. Design penelitian yang digunakan cross sectional study untuk mengetahui faktor yang berhubungan dengan kinerja petugas dalam penyediaan berkas rekam medis rawat jalan. Populasi dalam penelitian ini adalah petugas dalam penyediaan berkas rekam medis yaitu admission dan perekam medis yang berjumlah 61 orang.

Data dalam penelitian ini bersumber dari data primer dan data sekunder. Analisis data yang digunakan yaitu univariat dan bivariat. Analisis bivariat dilakukan dengan membuat tabel silang (contingency) antara variabel bebas dan variabel terikat. Uji statistik yang digunakan adalah uji Chi square yang bertujuan untuk mempelajari hubungan antara dua variabel dengan derajat kepercayaan $95 \%(\alpha=0,05)$.

\section{HASIL PENELITIAN}

Analisa Univariat: Pengetahuan yang berhubungan dengan kinerja petugas dalam penyediaan berkas rekam medis rawat jalan sebesar 33 (54,09\%) dan komunikasi dalam penyediaan berkas rekam medis rawat jalan sebesar $28 \quad(45,9 \%)$ dari 61 jumlah 
responden.

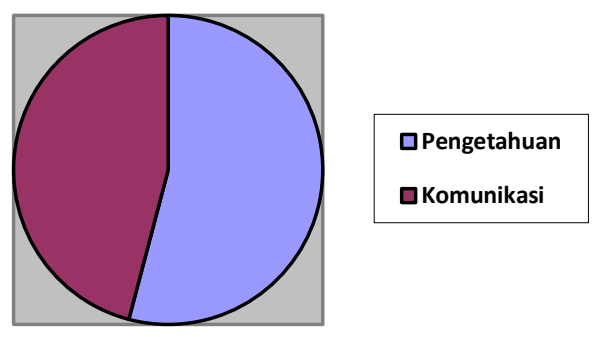

Analisa Bivariat: Umur pra lansia yaitu 45 hingga 59 tahun (menurut depkes 2013) ada $7(25,0 \%)$ responden untuk kinerja petugas yang kurang baik dan kinerja petugas yang baik sebanyak 23 $(75,0 \%)$ responden. Serta didapatkan nilai $\mathrm{P}$ $=0,072$ dan nilai alpa sebesar 0,05 .

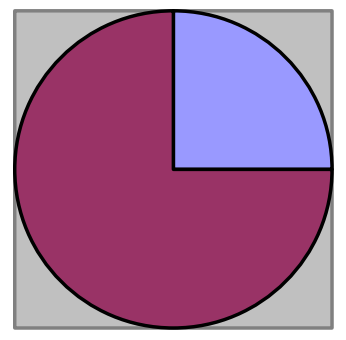

口kurang baik

$\square$ baik

Usia madya yaitu dimulai dari umur 40 tahun hingga 60 tahun(Hurlock, 1980) ada 5 $(50,0 \%)$ responden untuk kinerja petugas yang kurang baik dan kinerja petugas yang baik sebanyak $5(50,0 \%)$ responden. Serta didapatkan nilai $\mathrm{P}=0,485$ dan nilai alpa sebesar 0,05 .

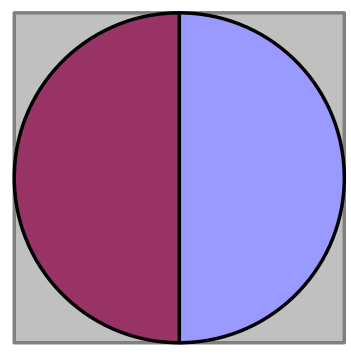

口kurang baik

口baik

Masa kerja ada $13(43,3 \%)$ responden untuk kinerja petugas yang kurang baik dan kinerja petugas yang baik sebanyak 17 $(56,7 \%)$. Dari 61 reponden untuk pengetahuan kurang baik ada $13(43,3 \%)$ responden untuk kinerja petugas yang kurang baik dan kinerja petugas yang baik hanya $6(33,3 \%)$ responden. dan didapatkan nilai $\mathrm{P}=0,008$ dan nilai alpa sebesar 0,05 . Komunikasi kurang baik ada $16(57,1 \%)$ responden untuk kinerja petugas yang kurang baik dan kinerja petugas yang baik hanya $12 \quad(42,9)$ responden. Serta didapatkan nilai $\mathrm{P}=0,011$ dan nilai alpa sebesar 0,05. dari 57 responden yang kinerja kurang baik yang tidak sesuai 4 $(21,1 \%)$ responden untuk kinerja petugas yang kurang baik dan kinerja petugas yang baik sebanyak $15(78,9)$ responden. dan didapatkan nilai $\mathrm{P}=0,102$ dan nilai alpa sebesar 0,05 .

\begin{tabular}{|c|c|c|c|}
\hline No & Kriteria Hasil & P Value & POR \\
\hline 1. & $\begin{array}{l}\text { Usia tidak } \\
\text { berhubungan } \\
\text { dengan kinerja } \\
\text { petugas }\end{array}$ & 0,072 & 0,311 \\
\hline 2. & $\begin{array}{l}\text { pendidikan tidak } \\
\text { berhubungan } \\
\text { dengan kinerja } \\
\text { petugas }\end{array}$ & 0,485 & 1,765 \\
\hline 3. & $\begin{array}{l}\text { masa kerja tidak } \\
\text { berhubungan } \\
\text { dengan kinerja } \\
\text { petugas }\end{array}$ & 0,616 & 1,529 \\
\hline 4. & $\begin{array}{l}\text { pengetahuan } \\
\text { berhubungan } \\
\text { dengan kinerja } \\
\text { petugas }\end{array}$ & 0,008 & 5,800 \\
\hline 5. & $\begin{array}{l}\text { komunikasi } \\
\text { berhubungan } \\
\text { dengan kinerja } \\
\text { petugas }\end{array}$ & 0,011 & 5,111 \\
\hline 6. & $\begin{array}{l}\text { SOP tidak } \\
\text { berhubungan } \\
\text { dengan kinerja } \\
\text { petugas }\end{array}$ & 0,102 & 0,296 \\
\hline
\end{tabular}

\section{PEMBAHASAN}

Kompetensi perekam medis (pengetahuan dan keterampilan), menunjukkan bahwa kedua variabel tersebut mempunyai hubungan signifikan terhadap kinerja petugas dalam penyediaan berkas rekam medis rawat jalan. 
Dari uji statistik untuk variabel pengetahuan didapatkan nilai $\mathrm{p}=0,008$ dan nilai alpa sebesar 0,05 . Nilai $P$ tersebut lebih kecil dari nilai alpa, yang artinya melalui hasil analisis statistik terdapat hubungan antara pengetahuan dengan kinerja petugas dalam penyediaan berkas rekam medis rawat jalan di Rumah Sakit TK.II dr.Soepraoen Malang. Nilai POR = 5,800 artinya bahwa petugas perekam medis yang mempunyai pengetahuan kurang baik mempunyai peluang 5,8 kali memiliki kinerja yang kurang baik dibandingkan dengan petugas rekam medis yang mempunyai pengetahuan yang baik.

Pengetahuan merupakan penginderaan manusia, atau hasil tahu seseorang terhadap objek melalui indra yang dimilikinya. Maka dari itu dengan sendirinya, pada waktu pengindraan sampai dengan menghasilkan pengetahuan tersebut sangat dipengaruhi oleh intensitas perhatian dan persepsi terhadap objek. Sebagian besar pengetahuan seseorang diperoleh melalui indra pendengaran dan penglihatan (Notoatmodjo, 2012).

Dari uji statistik didapatkan nilai $\mathrm{p}=$ 0,011dan nilai alpa sebesar 0,05 . Nilai $p$ tersebut lebih kecil dari nilai alpa, yang artinya melalui hasil analisis statistik terdapat hubungan antara komunikasi dengan kinerja petugas dalam penyediaan berkas rekam medis rawat jalan di Rumah Sakit TK.II dr.Soepraoen Malang Nilai $\mathrm{POR}=5,111$ artinya bahwa petugas rekam medis yang mempunyai komunikasi kurang baik mempunyai peluang 5,111 kali memiliki kinerja yang kurang baik dibandingkan dengan petugas rekam medis yang mempunyai komunikasi yang baik. komunikasi adalah proses penyampaian informasi, gagasan, fakta, Dalam kehidupan organisasi, komunikasi menjadi sesuatu yang sangat penting karena komunikasi dapat meningkatkan saling pengertian antara karyawan dan atasan dan meningkatkan koordinasi dari berbagai macam kegiatan yang berbeda (Hariandia, 2002).

Sejalan dengan penelitian Hutagalung (2006) tentang analisis faktor yang mempengaruhi waktu tunggu pelayanan di rekam medis rawat jalan (studi di Rekam Medis Rawat Jalan RSU Haji Surabaya), didapatkan hasil uji statistik Chi Square diperoleh p-value 0,005 lebih kecil dari $\alpha$ 0,05. Hal ini menunjukkan bahwa terdapat hubungan yang bermakna antara komunikasi dengan kinerja petugas dalam penyediaan berkas rekam medis.

\section{KESIMPULAN}

$\begin{array}{r}\text { Hubungan } \\ \text { kompetensi petugas } \\ \text { rekam medis dangetahuan }\end{array}$
komunikasi) dengan kinerja petugas
penyediaan berkas rekam medis rawat jalan
dengan nilai $\mathrm{P}$ value pengetahuan $=0,008$,
nilai POR $=5,800$ dan $\mathrm{P}$ value komunikasi
$=0,011$, nilai $\mathrm{POR}=5,111$.

\section{DAFTAR PUSTAKA}

DepKes RI (1997). Pedoman pengelolaan rekam medis rumah sakit di Indonesia Revisi 1. Jakarta : Direktorat Jendral Pelayanan Medik.

, Pedoman Penyelenggaraan dan Prosedur Rekam Medis Rumah Sakit di Indonesia. Jakarta.

(2007). Buku Petunjuk Pengisian Pengolahan dan Penyajian Data Rumah Sakit. Jakarta. 
Jurnal Kesehatan Hesti Wira Sakti vol 9 No 12021

ISSN 2302-4283 (print)

ISSN 2580-9571 (online)

Online di https://jurnal.poltekkes-soepraoen.ac.id DOI: $10.47794 /$

Hariandja, M.T.E, (2002). Manajemen

Sumber Daya Manusia, Edisi Kedua,

Jakarta: Grasindo

Hutagalung, 2006. Pengembangan

Kepribadian. Bekasi: Direktorat

Jendral Manajemen Pendidikan

Dasar dan Menengah Kementrian

Pendidikan Nasional.

Nursalam. (2001). Pendidikan Dalam

Keperawatan, Jakarta: Salemba

Medika.

Notoatmodjo, S. (2005). Metodologi

Penelitian Kesehatan. Jakarta:

Rineka Cipta.

(2012). Metodologi

penelitian kesehatan. Jakarta : Rineka Cipta

Nursalam (2001). Pendidikan Dalam

keperawatan, Jakarta: Penerbit

Salemba Medika

Surgiyono (2010). Metode Penelitian

Kuantitatif dan Kualitatif. Bandung:

Alfabeta 